water, and it is peculiarly unfortunate that Chicago, the largest city on the lakes, stands on a sinking plain that is now but little above the high-water level of Lake Michigan.

The two volumes on mineral resources contain a large amount of valuable information, much of it statistical. The products for 1896 showed only a slight increase in value over those for $\mathrm{r} 895$. There are lengthy reports on iron-ores, on the iron and steel industries of all countries, and on the Witwatersrand banket and other goldbearing conglomerates, most of which appear to be marine. The evidence given in reference to these auriferous deposits shows that in ancient formations the detrital gold is most likely to be found in marine shore deposits. There are shorter reports on copper, lead and zinc, on aluminium with references to bauxite from Georgia and Alabama, on quicksilver, manganese, nickel, cobalt, antimony, and platinum ; 163 ounces of platinum were obtained in the United States, and it is mentioned that a nugget weighing 20 ounces was found in Columbia, South America. Coal and coke are treated very fully, so also are petroleum and natural gas. Building-stones, clays, cement, precious stones, phosphates, mineral paints, and a variety of other substences are dealt with. It is noted that black shale is ground for the pigment known as mineral black. Fuller's earth has been reported from a number of localities. Observations have been made on various limestones considered likely to be useful for lithography, and it is reported that South Dakota promises to furnish suitable stone. The final report is devoted to mineral waters.

\section{THE REPORT OF THE INTERNATIONAL AERONAUTICAL SOCIETY.}

THE International Meteorological Conference of Paris, I896 (NATURE, vol. liv. p. 523) appointed various committees to discuss and report on certain scientific questions. One of these committees was entrusted with all questions connected with the science of aeronautics, such as the scientific use of balloons and kites.

Of this committee, Dr. H. Hergesell of Strassburg was the chairman, and Dr. W. de Fonvielle the secretary.

The committee held a meeting at Strassburg, March $3 \mathrm{I}$-April 4,1898 , and the report of this meeting, in two languages-German and French-has just appeared.

The meeting was attended by some twenty-five gentlemen, for the most part original or co-opted members of the committee.

During the interval of eighteen months between the meeting in Paris and that at Strassburg, several con. certed balloon ascents had been organised and carried out. The area over which balloons, either manned or simply fitted with registering apparatus, had been sent up, extended from St. Petersburg to Paris, and a fair number of balloons took part on each occasion.

The chief business of the Strassburg meeting was to receive and consider the reports of these concerted experiments, and from the experience gained to arrive, if possible, at improvements in apparatus and arrangements for future work.

Among other matters, the preparation of sufficiently sensitive thermographs, to register sudden alternations of temperature, was especially recommended, and also the use of liquid air for the purpose of testing thermometers liable to exposure to extreme temperatures in unmanned balloons.

An interesting paper by $\mathrm{Mr}$. Rotch on his kite work at Blue Hill Observatory, Massachusetts, was also handed in and included in the report.

Various special reports will be found in the appendices.

\section{NOTES.}

A Deputation will wait upon Mr. Balfour to-day to place before him reasons why national support should be given to an Antarctic expedition. It is understond that the Government is favourably inclined to the views of the deputation, and that the intention to make a grant towards the cost of the proposed expedition will be announced.

Prof. E. A. Schäfer, F.R.S., has been elected successor to the late Prof. Rutherford in the chair of physiology in the University of Edinburgh. Prof. Schäfer is forty-three years of age, and he has been Jodrell professor of physiology in University College, London, since I863, when he succeeded Sir J. S. Burdon Sanderson.

THE annual conversazione of the Royal Society took place yesterday evening as we went to press.

Sir W. H. White, K.C.B., F.R.S., will receive the freedom of the borough of Devonport on July 20 , and will unveil, at the Technical School, a window descriptive of naval architecture.

DR. W. F. HUME, who during the last eight months has been carrying out a geological and topographical survey of the peninsula of Sinai, under the auspices of the Egyptian Government, has returned to Cairo with his survey party.

Dr. Cyrus Adler contributes to Science of June 2 and 9 a detailed account of the proceedings of the second conference on the International Catalogue of Scientific Literature, held at the Royal Society last October. The official Acta of the conference appeared in NATURE of October 27, I898 (vol. Iviii. p. 623).

M. Ph. van Tieghem, Professor at the Museum of Natural History and President of the French Academy of Sciences, has been appointed to the chair of Biology of plants cultivated in France and the Colonies at the National Agronomic Institute, Paris; and M. G. Poirault succeeds the late M. Naudin as Director of the Laboratory for Higher Instruction at the Villa Thuret, Antibes.

Prof. Alfred Grard, the president of the section of zoology, anatomy, and physiology of the French Association for the Advancement of Science, has issued a circular in which he points out that as zoological members of the British Association will visit Boulogne, and attend some of the meetings of the French Association, the meeting will afford a good opportunity of discussing questions referring to pisciculture and marine fisheries. Papers dealing with the special zoology of the Channel or of the North Sea are therefore especially invited.

THE International Hydrographic and Biological Congress, which is to discuss the arrangement of periodical researches into the conditions of the North Sea and North Atlantic, was opened at Stockholm on Thursday last. M. Krusenstjerna, Minister of the Interior, delivered a speech, in which he welcomed the delegates in the name of the King of Sweden and Norway. Director-General Akermann (Sweden) was chosen president of the congress.

THE Liverpool School of Tropical Diseases is sending out to the West African coast a special expedition to investigate the causes of malaria and other diseases. The expedition will be headed by Major Ross, the recently-appointed lecturer, and will include Dr. Sunnett, the demonstrator to the Liverpool School. The party will start for Sierra Leone early in August, when the malarial season is at its height, and the conditions are most favourable for research. The expedition hopes to determine, by the methods which Major Ross employed in India,

NO. 1547 , vOL. 6o] 